Bangladesh J. Sci. Res. 29(2): 133-141, 2016 (December)

\title{
QUALITY OF WATER AND SEDIMENT OF DIFFERENT COTTAGE INDUSTRIES WATER BODIES: A CASE STUDY
}

\author{
Farzana Yasmin ${ }^{1}$, Sayma Khanom* and Md. Sunjid Sultan Ferdous \\ Department of Soil, Water and Environment, University of Dhaka, \\ Dhaka-1000, Bangladesh
}

\begin{abstract}
This study was carried out in order to assess the effect of industrial effluents on the surface water and sediment around BSCIC industrial area, Narayanganj. Different parameters such as TDS, DO, pH, EC, Turbidity, BOD, COD, and heavy metals such as $\mathrm{Pb}, \mathrm{Zn}, \mathrm{Cd}, \mathrm{Mn}, \mathrm{Cr}$ and $\mathrm{Ni}$ were investigated. The results showed that, different industries inside the BSCIC area discharge effluents composed of various chemicals at considerably higher levels compared to pollution limits of inland surface water standard given by DoE. Significantly higher levels of EC $(3540 \mu \mathrm{S} / \mathrm{cm})$, TDS $(3862 \mathrm{mg} / \mathrm{l})$, BOD $(143.71 \mathrm{mg} / \mathrm{l})$ and COD $(396.30 \mathrm{mg} / \mathrm{l})$ were found in the water. Also a higher level of heavy metals along with high $\mathrm{pH}$ was found both for the water and sediment around the $\mathrm{BSCIC}$ area. A significant correlation was found between the $\mathrm{pH}, \mathrm{EC}$ and heavy metal concentration of the collected water samples. The above findings point out that the water around the studied area is quite polluted by the industrial activities of the BSCIC area and malicious for surrounding environment.
\end{abstract}

Key words: Quality water, BSCIC area, effluent, sediment, heavy metals

\section{Introduction}

Industrial development is essentially a prerequisite for the socio-economic development of a nation. On the other hand, it is intimately related to the environment. In the light of waste generation in Bangladesh, Bangladesh Small and Cottage Industries Corporation (BSCIC) is providing infrastructural facilities, having established 79 industrial estates throughout the country that are generating a large amount of wastes or refuse from everyday operation and maintenance. BSCIC industries are manufacturing and assembling a variety of products that releases different types of wastes often without any treatment at all (Rahman et al. 2014). Industrial wastes comprise different types of solid waste, liquid waste, and gaseous waste. Their characteristics are different from the municipal and the commercial wastes. The careless disposal of industrial effluents and other wastes may contribute greatly to the poor quality of the water (Chindah et al. 2004). The waste generation quantity differs from industry to industry.

The BSCIC area, Narayanganj is one of the prominent industrial sectors of Bangladesh. Different types of industries are situated in Narayanganj BSCIC area. Of them approximately $80 \%$

*Corresponding author: <sayma_swedu@yahoo.com>, ${ }^{1}$ Present address: Centre for Advanced Research in Sciences, University of Dhaka, Dhaka-1000, Bangladesh. 
industries are textiles dyeing industries, which discharge huge amount of effluents, sewage sludge and solid waste materials directly into the surrounding water body of this area. A major environmental hazard in textile industries is the discharge of untreated effluent to the environment, causing pollution of nearby soil and water (Islam et al. 2011). Many different groups of chemical substances are used in the textiles sector, including dyes, solvents, optical brighteners, creaseresistance agents, flame retardants, heavy metals, pesticides, and antimicrobic agents. They are used in dyeing, printing, finishing, bleaching, washing, dry cleaning, weaving slashing/sizing, and spinning. These effluents offer the alteration of physical, chemical and biological properties of aquatic environment by causing change in temperature, odor, noise, turbidity and to the original properties that is harmful to public health, livestock, wildlife, fish and other biodiversity (Haque et al. 2002). Contamination to the aquatic system brings serious threat to the overall epidemic and socio-economic pattern around the industrial area.

There are a large numbers of textile dyeing industries functioning in the BSCIC area. Moreover, pharmaceuticals industry, food manufacturing industry, cottage industry, plastic and rubber product, paper and paper product, leather goods and products are also situated inside this area. More than $80 \%$ industries have no large industrial treatment plant for effluent discharge. Furthermore, there are limited data found about the different BSCIC areas of Bangladesh specially about Narayanganj BSCIC area. So, proper analysis is needed to assess the pollution level also for the protection of environment and natural resources. Therefore, the present study was undertaken to determine the concentration and extent of pollution level of the surrounding water body of the Narayanganj BSCIC area.

\section{Materials and Methods}

Narayanganj BSCIC area was selected as the study area (Fig. 1). In this study, the sampling sites are located in the main discharge canal around the BSCIC area. Thirteen water samples were collected from different points of the canal surrounding the studied area and 13 samples of sediment were also collected from the same points. Collection and analysis of the samples were performed in August, 2014 by proper sampling procedure.

Water samples were collected in $500 \mathrm{ml}$ plastic bottles covering the whole drainage canal starting from the one end of the canal to the other end at an interval of around $50 \mathrm{~m}$. The samples were taken from the mid-stream and approximately 0.30 meters below the surface. Sediment samples were collected in polythene bags and labelled with the name and date. For laboratory analysis two sets of water samples were collected in plastic bottles from each point. One set was used for determination of BOD, COD, DO, $\mathrm{pH}$ and EC immediately after collection where no acid was added and another set was mixed with $4-5$ drops of $2 \mathrm{M} \mathrm{HCl}$ acid which was used for all other physicochemical analysis such as total dissolved solids (TDS) and heavy metals such as chromium $(\mathrm{Cr})$, cadmium $(\mathrm{Cd})$, iron $(\mathrm{Fe})$, lead $(\mathrm{Pb})$, manganese $(\mathrm{Mn})$ and zinc $(\mathrm{Zn})$.

Physicochemical parameters such as color, odor, temperature, total dissolved solid (TDS), dissolved oxygen (DO), hydrogen-ion-concentration ( $\mathrm{pH}$ ), electrical conductivity (EC), turbidity, 
biochemical oxygen demand (BOD), chemical oxygen demand (COD) of the water samples were measured using various standard methods (APHA 1976). Further heavy metals, such as lead (Pb), zinc $(\mathrm{Zn})$, cadmium $(\mathrm{Cd})$, chromium $(\mathrm{Cr})$, nickel $(\mathrm{Ni})$ and manganese $(\mathrm{Mn})$ concentrations of both water and sediment samples were determined by using atomic absorption spectrophotometer as described by Jackson (1962). The data were analyzed by statistical software SPSS (version 20).

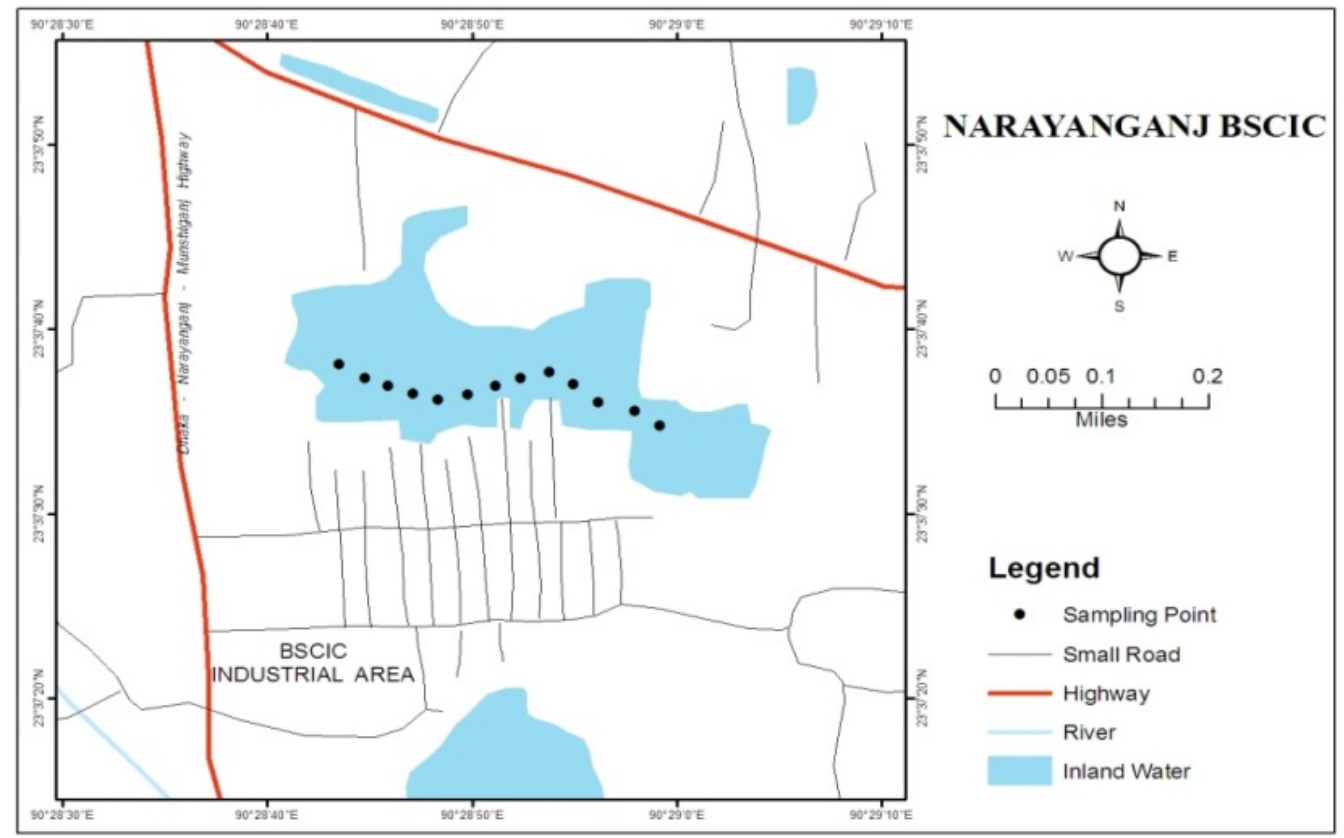

Fig 1. BSCIC area of Narayanganj.

\section{Results and Discussion}

Surface water: Average concentration of different physico-chemical parameters of the water samples and its comparison with the inland surface water standard values recommended by DoE (2008), Bangladesh is presented in Table 1.

Color, odor and temperature: The color of the surface water was dark with pungent odor which emits noxious smell. But according to DoE standard water should be colorless and odorless. Therefore, the water was unsuitable not only for aquaculture but also for domestic, industrial, agricultural, or fish culture purposes. The average temperature of the water was found about $42^{\circ} \mathrm{C}$ which is slightly higher than DoE standard (Table 1). This high temperature might be due to discharge of boiling water of different textile dyeing industries.

$p H$ : Table 1 reveals that higher value of $\mathrm{pH}$ was measured 9.10 at point 9 and lowest was measured to be 8.53 at point 2 which indicated that the water was alkaline and has already reached the upper limit of DoE standard. The $\mathrm{pH}$ variation may be caused by different kinds of dye stuff 
used in the dyeing process in different industries. In textile dyeing industries $\mathrm{H}_{2} \mathrm{O}_{2}$ and $\mathrm{NaOH}$ are used as bleaching and kier agents. Higher $\mathrm{pH}$ approaches in waste water owing to the wastes composition of textile mills such as $\mathrm{NaOCl}, \mathrm{NaOH}, \mathrm{Na}_{2} \mathrm{SiO}_{3}$, surfactants and sodium phosphate (Sultana et al. 2009).

Table 1. Descriptive statistics of the physicochemical parameters of the surface water.

\begin{tabular}{llllll}
\hline Parameter & Maximum & Minimum & Mean & Sd. \pm error & DoE standard, 2008 \\
\hline Temperature $\left({ }^{\circ} \mathrm{C}\right)$ & 46.8 & 37.2 & 42.0 & $0.21 \pm 0.03$ & 40 \\
$\mathrm{pH}$ & 9.10 & 8.53 & 8.74 & $0.16 \pm 0.05$ & $6-9$ \\
$\mathrm{EC}(\mu \mathrm{S} / \mathrm{cm})$ & 3540.00 & 2712.00 & 2938.62 & $276.69 \pm 76.74$ & 1200 \\
Turbidity (NTU) & 101.31 & 45.70 & 72.60 & $18.03 \pm 5.00$ & - \\
TDS $(\mathrm{mg} / \mathrm{l})$ & 3862.00 & 2249.00 & 2968.15 & $470.16 \pm 130.40$ & 2100 \\
DO " & 3.08 & 0.59 & 1.84 & $0.60 \pm 0.14$ & $4.5-8$ \\
BOD " & 143.71 & 32.89 & 68.66 & $34.55 \pm 9.58$ & 50 \\
COD " & 396.30 & 107.16 & 228.52 & $89.11 \pm 24.72$ & 200 \\
\hline
\end{tabular}

EC: The electric conductivity (EC) is usually used for indicating the total concentration of the ionized constituents of water. The values of EC of the water of the study area varied from 2712 to $3540 \mu \mathrm{s} / \mathrm{cm}$ which indicates the greater amount of salts in the water. The concentration of EC is highest in point 9 and lowest in point 2. The EC was two - three times higher than the DoE standard. It might be due to dumping of solid wastes and discharging of industrial effluents (Irshad et al. 2011).

Turbidity: The turbidity of the water samples ranged between 101.31 and 45.70 NTU. Turbidity in water is caused by suspended and colloidal matter such as clay, silt, finely divided organic and inorganic matter, and plankton and other microscopic organisms. A similar trend was also found in another study at DEPZ industrial area, Savar (Momtaz et al. 2012).

TDS: Water that contains more than $1000 \mathrm{ppm}$ of dissolved solids usually contains minerals that give it a distinctive taste or make it unsuitable for human consumption (Irshad et al. 2011). Total dissolved solid (TDS) of the study area ranged from 2249 to $3862 \mathrm{mg} / 1$ which was higher than the DoE standard for inland surface water quality $(2100 \mathrm{mg} / \mathrm{l})$ and much higher than the standard limit $250 \mathrm{mg} / \mathrm{l}$ for drinking purpose (Davis and Cornwell 1998). The highest TDS results in point 1 and lowest in point 8 . The high amount of dissolved solids in water increases the water density; it influences osmoregulation of freshwater organisms and reduces solubility of gases. Increased $\mathrm{pH}$ value of the sample might have resulted in the dissolution of low molecular mass organic bases originating from dye industries. This also gives rise to higher TDS value (Moore et al. 1960). As the value of $\mathrm{pH}$ of study area was high, the value of TDS was also high (Table 1).

DO: The presence of sufficient DO in water is a positive sign of a healthy water body but the deficiency of DO is a signal of pollution. The level of DO varied from $0.59 \mathrm{mg} / \mathrm{l}$ at point 9 to 3.08 
$\mathrm{mg} / \mathrm{l}$ at point 13 which was much below the limit of DoE standard (4.5 - 8), suggesting that the industries were releasing a lot of organic substances most likely the dyes that were high oxygen demanding wastes (Emongor et al. 2005). Deficiency of DO in water gives rise to odoriferous products of anaerobic decomposition. High TDS is one of the major sources of sediments which reduce the light penetration into water and ultimately decrease the photosynthesis. The decrease in photosynthetic rate reduces the DO level of waste water which results in decreased purification of waste water by microorganisms (Tyagi and Mehra 1990).

$B O D$ : Biochemical oxygen demand is the quantity of oxygen required by bacteria and other microorganisms during the biochemical degradation and transformation of organic matter present in water under aerobic conditions (Dara 2002). $\mathrm{BOD}_{5}$ is an index of the biodegradable organics present. The industries in the BSCIC area releases a lot of biochemical oxygen demanding wastes such as many dyes contain organic compounds with functional groups, such as carboxylic ($\mathrm{COOH})$, amine $\left(-\mathrm{NH}_{2}\right)$, and azo $(-\mathrm{N}=\mathrm{N}-)$ groups (Babu et al. 2007). Biochemical oxygen demanding wastes consume the dissolved oxygen from water. The average value of $\mathrm{BOD}_{5}$ varied from $32.89 \mathrm{mg} / \mathrm{l}$ at point 12 to $143.71 \mathrm{mg} / \mathrm{l}$ at point 4 which was higher than the limit of DoE (Table 1). So this high value of $\mathrm{BOD}_{5}$ indicates the status of oxygen deficiency in water body which can cause serious damage to aquatic flora and fauna like fish and microorganisms (Kabir et al. 2002).

COD: The chemical oxygen demand is commonly used to indirectly measure the amount of organic compounds in water. Most applications of COD determine the amount of organic pollutants found in surface water (e.g. lakes and rivers) or waste water, making COD a useful measure of water quality. The average value of COD of water samples varied from 107.16 to $396.30 \mathrm{mg} / \mathrm{l}$. In some points COD were found two times higher than the limit of DoE (200 mg/l) (Table 1). Highest COD was found at point 3 and lowest was found at point 13.

Heavy metals: In the study area, average concentrations of $\mathrm{Zn}, \mathrm{Mn}, \mathrm{Cd}, \mathrm{Pb}, \mathrm{Cr}$ and $\mathrm{Ni}$ were higher than the limit of DoE standard for inland water quality (Table 2). Zinc content of the water samples ranged from 9.188 to $2.184 \mathrm{mg} / \mathrm{l}$ with an average of $5.56 \mathrm{mg} / \mathrm{l}$. The highest value of $\mathrm{Zn}$ found at point 1 was two times higher than the limit of DoE. Lowest $\mathrm{Zn}$ was found at point 13.

Table 2. Descriptive statistics of the heavy metals of surface water.

\begin{tabular}{lccccc}
\hline Parameter & Maximum & Minimum & Mean & Sd. \pm error & DoE standard, 2008 \\
\hline $\mathrm{Zn}$ & 9.19 & 2.18 & 5.56 & $2.19 \pm 0.61$ & 5.0 \\
$\mathrm{Mn}$ & 12.26 & 4.12 & 7.94 & $2.22 \pm 0.61$ & 5.0 \\
$\mathrm{Cd}$ & 0.12 & 0.03 & 0.07 & $0.03 \pm 0.01$ & 0.05 \\
$\mathrm{~Pb}$ & 0.46 & 0.01 & 0.25 & $0.14 \pm 0.04$ & 0.1 \\
$\mathrm{Cr}$ & 2.10 & 0.54 & 1.19 & $0.49 \pm 0.14$ & 0.5 \\
$\mathrm{Ni}$ & 4.52 & 1.45 & 3.08 & $0.94 \pm 0.26$ & 1.0 \\
\hline
\end{tabular}

Average manganese concentration was found 7.94 which was higher than the DoE standard with a highest value found at point 1 and lowest at point 13. Lead content ranged from $0.46 \mathrm{mg} / \mathrm{l}$ 
at point 2 to $0.01 \mathrm{mg} / \mathrm{l}$ at point 13 , with an average value of $0.25 \mathrm{mg} / \mathrm{l}$. The content of cadmium range from 0.12 to $0.03 \mathrm{mg} / \mathrm{l}$ in different points. Highest value of chromium was $2.10 \mathrm{mg} / \mathrm{l}$ which was almost 4 times higher than the DoE standard and the lowest value was $0.54 \mathrm{mg} / \mathrm{l}$. While average nickel content was found 3.08 which was three times higher than the DoE standard. Trend of the heavy metal concentration in the water samples were: $\mathrm{Mn}>\mathrm{Zn}>\mathrm{Ni}>\mathrm{Cr}>\mathrm{Pb}>\mathrm{Cd}$ while Momtaz et al. (2012) found heavy metals within DoE standard at DEPZ industrial area, Savar except for $\mathrm{Cr}$ at some points.

From Table 3 it can be seen that heavy metals are positively correlated with each other in the surface water at $\mathrm{p} \leq 0.05$. That is increase in any metal will increase the other heavy metal concentration of the water samples. Again, heavy metals are negatively correlated with $\mathrm{pH}$ and EC of the surface water at $p \leq 0.05$.

Table 3. Correlation among pH, EC and heavy metal concentrations of water.

\begin{tabular}{lcccccccc}
\hline & $\mathrm{pH}$ & $\mathrm{EC}$ & $\mathrm{Zn}$ & $\mathrm{Mn}$ & $\mathrm{Pb}$ & $\mathrm{Cd}$ & $\mathrm{Cr}$ & $\mathrm{Ni}$ \\
\hline $\mathrm{pH}$ & 1 & & & & & & & \\
$\mathrm{EC}$ & 0.927 & 1 & & & & & & \\
$\mathrm{Zn}$ & -0.304 & -0.345 & 1 & & & & & \\
$\mathrm{Mn}$ & -0.260 & -0.322 & 0.965 & 1 & & & & \\
$\mathrm{~Pb}$ & -0.303 & -0.368 & 0.957 & 0.921 & 1 & & & \\
$\mathrm{Cd}$ & -0.288 & -0.312 & 0.941 & 0.946 & 0.939 & 1 & & \\
$\mathrm{Cr}$ & -0.356 & -0.359 & 0.913 & 0.927 & 0.917 & 0.983 & 1 \\
$\mathrm{Ni}$ & -0.227 & -0.268 & 0.944 & 0.926 & 0.967 & 0.947 & 0.949 & 1 \\
\hline
\end{tabular}

Table 4. Descriptive statistics of the heavy metals of the sediment samples.

\begin{tabular}{lcccc}
\hline Parameter & Maximum & Minimum & Mean & Sd \pm error \\
\hline $\mathrm{pH}$ & 8.90 & 7.90 & 8.34 & $0.28 \pm 0.08$ \\
$\mathrm{Zn}$ & 7.57 & 0.76 & 3.64 & $2.65 \pm 0.73$ \\
$\mathrm{Mn}$ & 8.02 & 1.52 & 5.41 & $2.28 \pm 0.63$ \\
$\mathrm{~Pb}$ & 0.28 & 0.00 & 0.14 & $0.11 \pm 0.03$ \\
$\mathrm{Cd}$ & 0.09 & 0.03 & 0.06 & $0.02 \pm 0.01$ \\
$\mathrm{Cr}$ & 0.97 & 0.11 & 0.56 & $0.30 \pm 0.08$ \\
$\mathrm{Ni}$ & 2.68 & 0.09 & 0.99 & $0.83 \pm 0.23$ \\
\hline
\end{tabular}

Table 3 shows that increase in $\mathrm{pH}$ and EC will decrease the heavy metal concentration of the water samples and vice versa. The result suggests that heavy metals and other pollutant polluted the surface water. So the surface water is harmful for aqua culture, irrigation and recreational purposes.

Sediment: Sediments represent a potential source of contaminants to the overlying water and thus influence water quality. For the present study, sediment samples were collected and analyzed for $\mathrm{pH}, \mathrm{Zn}, \mathrm{Mn}, \mathrm{Pb}, \mathrm{Cd}, \mathrm{Cr}$ and $\mathrm{Ni}$ (Table 4). The lowest $\mathrm{pH}$ value was 7.90 and highest 
$\mathrm{pH}$ was 8.90. These higher values of $\mathrm{pH}$ may be due to alkaline discharge of the industrial effluents.
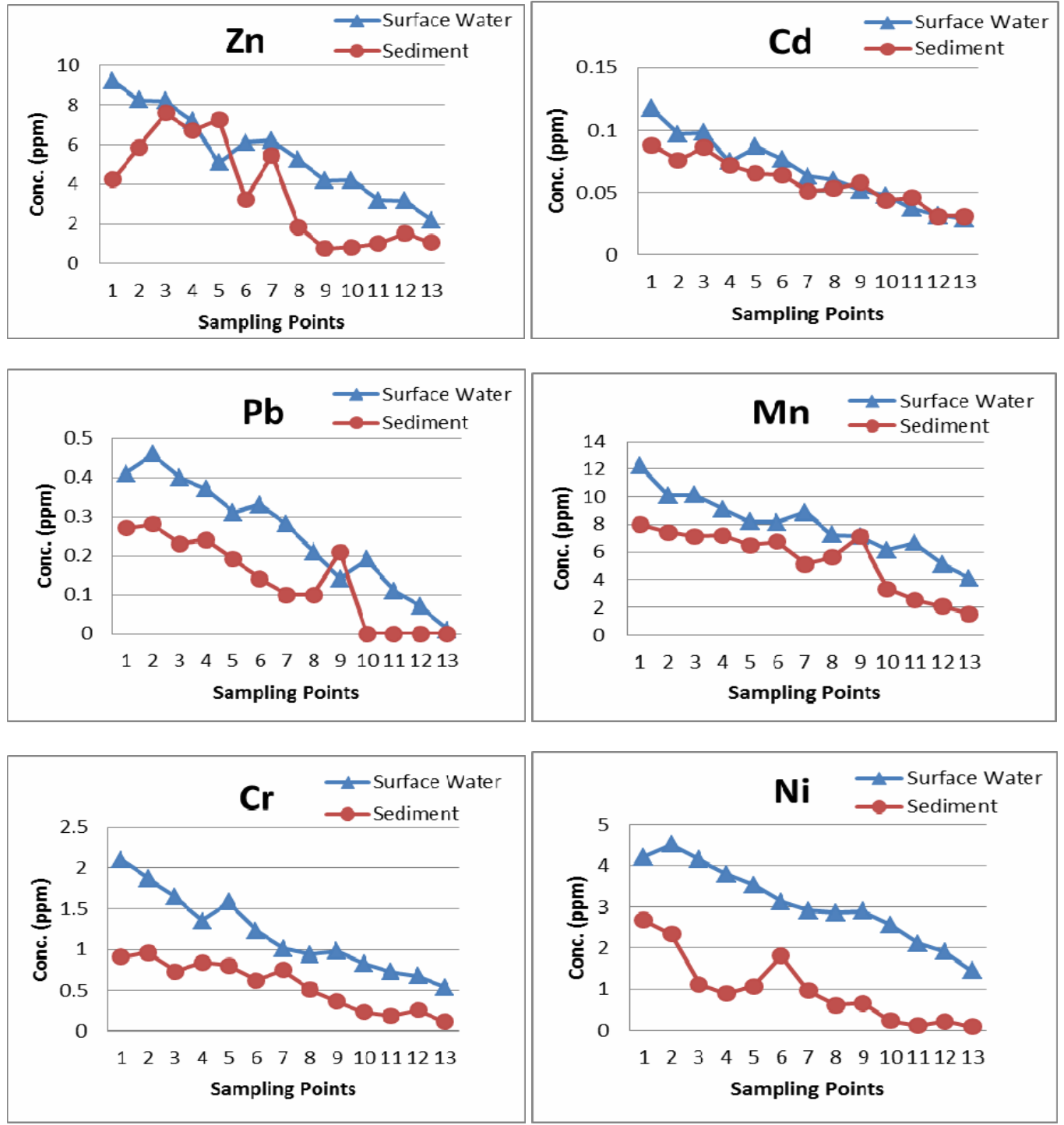

Fig. 2. Concentration of heavy metals in the sediments of the BSCIC area.

From Fig. 2 it can be seen that the maximum water samples contain more heavy metals than the sediment samples of the same points, specially $\mathrm{Cr}$ and $\mathrm{Ni}$. Zn was higher in the sediment than the surface water at sampling point 5. Mn concentration of the sediment has been decreased from the start point to the end point showing a peak at sampling point 9. This might be due to deposition of the heavy metals at this point. Similar trend was also found for Pb. Again, concentration of $\mathrm{Ni}$ was decreased continuously except a sudden increase at sampling point 6 . 
These peaks of different metals suggest that these points might get that specific metal from the nearby industries or the sampling point might be very close to the discharge canal. The above results suggest that, most of the soil contain much higher values of heavy metals than worldwide average soil value and have considerable negative effects on the soil quality and agricultural crops of the area and thus harmful for human health.

\section{Conclusion}

Industrial sector in Bangladesh releases huge amount of effluent to aquatic systems, which contain toxic and hazardous pollutants degrading the environment. BSCIC area in Narayanganj is one of the largest industrial areas. The reported $\mathrm{pH}, \mathrm{EC}$, turbidity, TDS, DO, BOD and COD were quite higher than the recommended values of DoE. Aquatic life hardly survives in such type of condition. Again, the content of metals like $\mathrm{Zn}, \mathrm{Mn}, \mathrm{Pb}, \mathrm{Cd}, \mathrm{Cr}$ and $\mathrm{Ni}$ were also higher than the permissible limit. Furthermore, heavy metal concentration in sediment was also higher than the standard value provided by DoE. So the present study shows that the surface water gets contaminated and polluted due to various chemicals used by the different industries of the study area. If the present scale of industrial pollution goes on without taking proper treatment action, the water quality will turn into a toxic and poisonous one in the long run and affect our surrounding environment.

\section{Reference}

APHA. 1976. Standard methods for the examination of water and wastewater (14th ed). American Public Health Association, Washington. p. 1193.

Babu, B. R., A. K. Parande, S. Raghu and T. P. Kumar. 2007. Cotton textile processing: waste generation and effluent treatment. The Journal of Cotton Science 11: 141-153.

Chindah, A. C., A. S. Braide and O. C. Sibeudu. 2004. Distribution of hydrocarbons and heavy metals in sediment and a crustacean (shrimps- Penaeus notialis) from the Bonny/New Calabar River Estuary, Niger Delta. African Journal of Environmental Assessment and Management 9: 1-17.

Dara, S. S. 2002. A Textbook of Environmental Chemistry and Pollution Control. S. Chand and Company Limited, New Delhi, India. pp. 24-30.

Davis, M. L. and D. A. Cornwell. 1998. Introduction to Environmental Engineering. WCB/McGraw-Hill Book Company, Singapore. pp. 469-535.

DoE, 2008. Environmental quality standards for Bangladesh. Department of Environment, Dhaka, Government of Bangladesh.

Emongor, V., E. Nkegbe, B. Kealotswe, I. Koorapetse, S. Sankwasa and S. Keikanetswe. 2005. Pollution indicators in Gaborone industrial effluent. Journal of Applied Sciences 5(1): 147-150.

Haque, S., H. Yasmin and M. H. Rahman. 2002. Environmental pollution in Bangladesh, Earth Community Organization (ECO). pp. 38-47.

Irshad, M., A. Faridullah, N. Malik and T. Khan. 2011. Effect of solid waste on heavy metal composition of soil and water at Nathiagali-Abbottabad. Journal of the Chemical Society of Pakistan 33(6): 830-834. 
Islam, M. M., K. Mahmud, O. Faruk and M. S. Billah. 2011. Textile dyeing industries in Bangladesh for sustainable development. International Journal of Environmental Science and Development 2(6): 428436.

Jackson, M. L. 1962. Soil chemical analysis. Prentice Hall of India Private Limited, New Delhi, India. pp. 1498.

Kabir, E. S., M. Kabir, S. M. Islam, C. M. Mia, N. Begum, D. Chowdhury, M. S. Sultana and S. M. Rahman. 2002. Assessment of effluent quality of Dhaka Export Processing Zone with special emphasis to the textile and dying industries. Jahangirnagar University Journal of Biological Science 25: 137-138.

Momtaz, H., F. Alam, M. A. Ahsan, M. A. Akbor and M. M. Rashid. 2012. Surface water quality around DEPZ industrial area, Savar, Dhaka. Bangladesh Journal of Scientific and Industrial Research 47(3): 279-286.

Moore, M., K. McLeod and D. Reed. 1960. Fisheries: Conservation, propagation and regulation, Washington Department of Fisheries, USA. pp. 155-163.

Rahman, M. S., S. Datta and S. Islam. 2014. Waste generation and management practices in BSCIC Mymensingh. Journal of Environmental Science and Natural Resources 7(1): 47-51.

Sultana, M. S., M. S. Islam, R. Saha and M. A. Mansur. 2009. Impact of the effluents of textile dyeing industries on the surface water quality inside D.N.D embankment, Narayanganj. Bangladesh Journal of Scientific and Industrial Research 44(1): 65-80.

Tyagi, O.D. and M. Mehra, 1990. A textbook of environmental chemistry. Anmol Publications, New Delhi, India. pp. 1-404.

(Manuscript received on 18 August, 2016; revised on 2 January, 2017) 